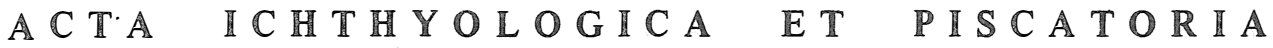

$\begin{array}{lr}\text { Voll. XX, Fasc. } 1 & \text { Szczecin } 1990\end{array}$

Iwona KOSTRZEWSKA-SZLAKOWSKA ${ }^{1}$, Jacek SZLAKOWSKI'

Fish biology

\title{
SUMMER FOOD OF JUVENILE TURBOT, PSETTA MAXIMA (L.) AND FLOUNDER, PLATICHTHYS FLESUS (L.), AT SWIETOUSŚC, POMERANIAN BAY
}

\author{
LETNI POKARM NARYBKU, PSETTA MAXIMA (L.) I STORNI. \\ PLATICHTHYS FLESUS (L.) Z REJONU SWTETOUSCIA, ZATOKA POMORSKA \\ 1 Institute of Ecology, Polish Academy of Sciences, Dzielkanów Lé̉ny \\ ${ }^{2}$ Institute of Zoology, Polish Academy of Sciences, Warazawa
}

Summer food of 0 -and I-age group turbot and flounder utilizing shallow, inshore nursery ground at Swiętouśc, Pomeranian Bay were examined. Juvenile turbot fed mostly on mysid. Neomysis integer, Pisces and Crangon crangon. Amphipod Bathyporeia piloss.was ot little importance. Juvenile flounder fed on polychaete, Nereis dibersicolor, and amphipod Bathyporeis pilloss and Gammorus spp. Tiny bottom-stages of Mollusca were of minor importance. Shifts in diet preferences as a function of fish size were observed in both species Owing to differences in diet composition practically no diet-overlap was found between larger turbot and flounder, from age group I. Between O-group fish, of these species, diet-over lap high as $36 \%$ for two food items shared, Colanotda and Bathyporeic pilosa, occurred.

\section{INTRODUCTION}

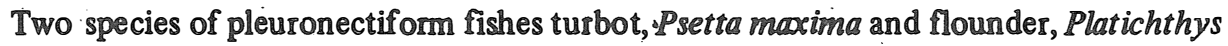
flesus, utilise the shallow, inshore nursery ground at Swiętouść, Pomeranian Bay, as a site of benthic recruitment, early growth and intensive f'eeding.

The flounder, Platichthys flesus $\left(\mathrm{L}_{\circ}\right)$, is the most abundant and the most commercially important flatfish dwelling in southern Baltic. Therefore the biology of this species, as well the food and feeding habits of adult and young fish are fairly good known. 
Feeding of flounder in the Baltic Sea was studied by Hertling (1928), Hessle (1930), Blegvad (1932), Mulicki (1947), Bolkova (1954), Żeltenkova (1954), Müller (1968), Szypuła and Załachowski (1978).

Little is known, however, of the feedning of the turbot; Psetta maxima $\left(\mathbb{L}_{.}\right)$. Only mentioned above, Hertling (1928) and Müller (1968) provided some data on the food of this fish.

The purpose of this paper was to examine and compare the prey composition in stomach contents, and its changes during the growth of juvenile turbot and flounder, age groups 0 and I, dwelling together in shallow, inshore nursery ground at Swiętouść, Pomeranian.Bay.

\section{MATERIALS AND METHODS}

Juvenile turbot were sampled in July 1982 and 1983 at Swwiętouść, Pomeranian Bay (Fig. 1). Some additional samples were talken in August/Septemiber 1984 and May 1985. Juvenile flounder were collected only; in July 1983. Total materials yielded in 313 specimens of turbot and 197 of flounder for food studies.

Juvenile flatfish were sampled with a $67 \times 75 \mathrm{~cm}$ hand push-net, which had a mesh size $7 \mathrm{~mm}$, at depths approximately from 0.1 to $1 \mathrm{~m}$.

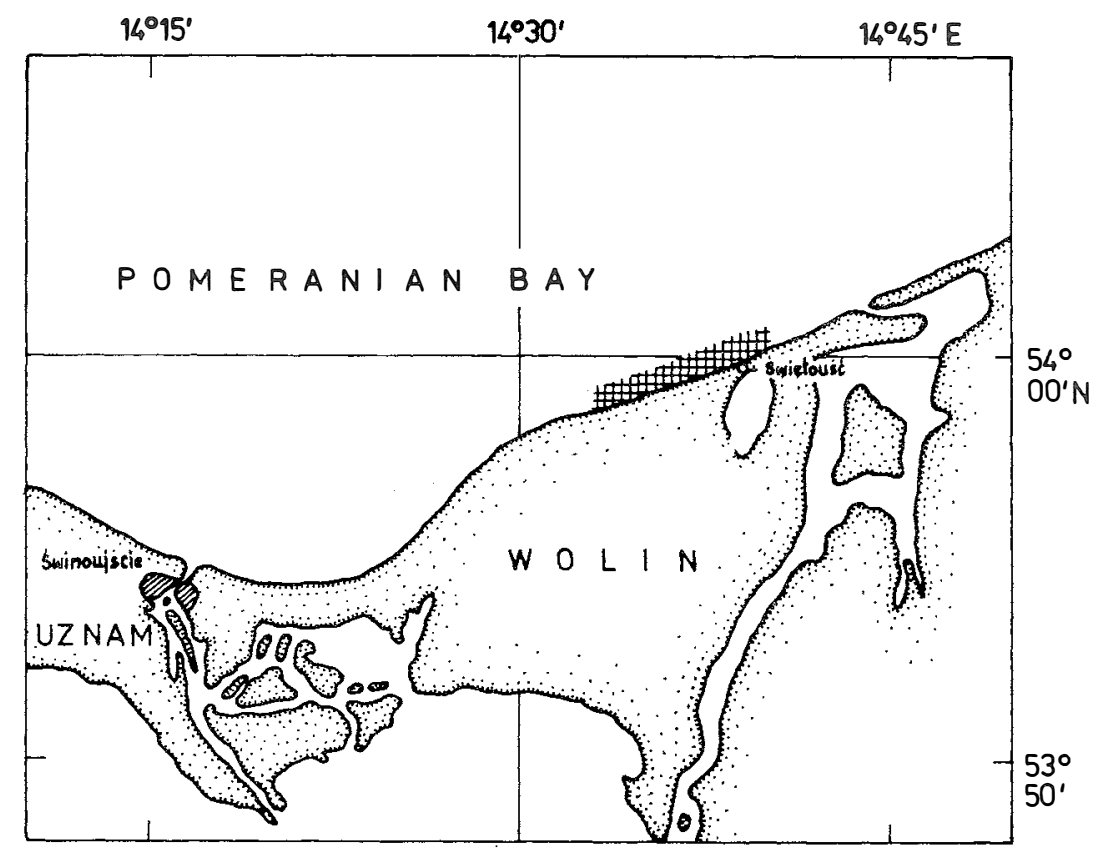

Fig. 1. Sampling area for juvenile turbot and flounder at Świętouść. Pomeranian Bay in 1982-85 yrs. 
Fish were preserved in $4 \%$ formalin in sea water and all subsequant analyses took places in the laboratory (in 1983 fish were measured and weighted before preservation). In the laboratory fish were measured to the millimetre below and weighted to $1 \mathrm{mg}$. Stomach contents of turbot and whole digestive tract contents of flounder were examined under binocular microscope. All food items were sorted and identified to the lowest possible taxon, then counted, measured to $0.1 \mathrm{~mm}$ and after removal of excess liquid on filter paper weighted to $1 \mathrm{mg}$. For the analyses of prey composition in the diet and dietary changes with size, fish were grouped into $1 \mathrm{~cm}$ length classes.

The importance of each prey group in the diet of flatfish was evaluated according to it percentages by frequency of occurrence $(\% \mathrm{~F})$ and percentages by weight $(\% \mathrm{~W}$; weights were reconstructed from weight standards, calculated by the authors or based on nomograms given 'by Czislenko, 1968). The percentages by number ( $\% \mathbb{N})$ was only used for computing two feeding indices for each prey item:

IRI=index of relative importance (Pinkas et al., 1971) $=(\% \mathrm{~N}+\% \mathrm{~W}) \mathrm{x} \% \mathrm{~F}$ and

MFI = main food item $($ Zander, 1982) $=\sqrt{((\% \mathbb{N}+\% \mathrm{~F}) / 2) \mathrm{x} \% \mathrm{~W})}$.

IRI stresses the frequency of occurrence, whereas MFI stresses the percentages by weight. In this paper these indices were expressed in percentages (\% $\mathbb{R} \mathbb{I}, \% \mathrm{MFI})$ to make comparison easier.

Diet overlap between turbot and flounder was calculated according to Shorygin (1952) by summing the smaller values, in this case the percentage of weights, for all prey items shared by the two species.

Accordingly:

$$
\text { D.O. }=\sum_{i=1}^{n} \min (a, b)
$$

where: D.O. = diet overlap (in \%),

$\mathrm{a}=$ percentage weight of a given prey item in the diet of species $\mathrm{A}$,

$\mathrm{b}=$ percentage weight of the same prey item in the diet of species $B$,

$\mathrm{n}=$ total number of prey items.

\section{RESULTS}

Prey composition.

Psetta maxima. The stomach contents of juvenile turbot consisted of six components (Table 1., Fig. 2):

1. Calanoid copepodite - Acartia spp., Pseudocalanus spp., Temora spp..

2. Amphipod - Bathyporeia pilosa.

3. Mysid - Neomysis integer.

4. Decapod - Crangon crangon.

5. Piscês - Pomatoschistus microps, P. minutus, Ammodytes tobianus, Lucioperca lucioperca (juv.), Platichthys flesus (juv.). 
Table 1

Psetta maxima. Prey composition by length classes. \%W: \% weight $\% \mathrm{~F} ; \%$ frequency of occurrence; \%N: \% number; \%IRI, \%MFI: percentage values of feeding indices of prey categories

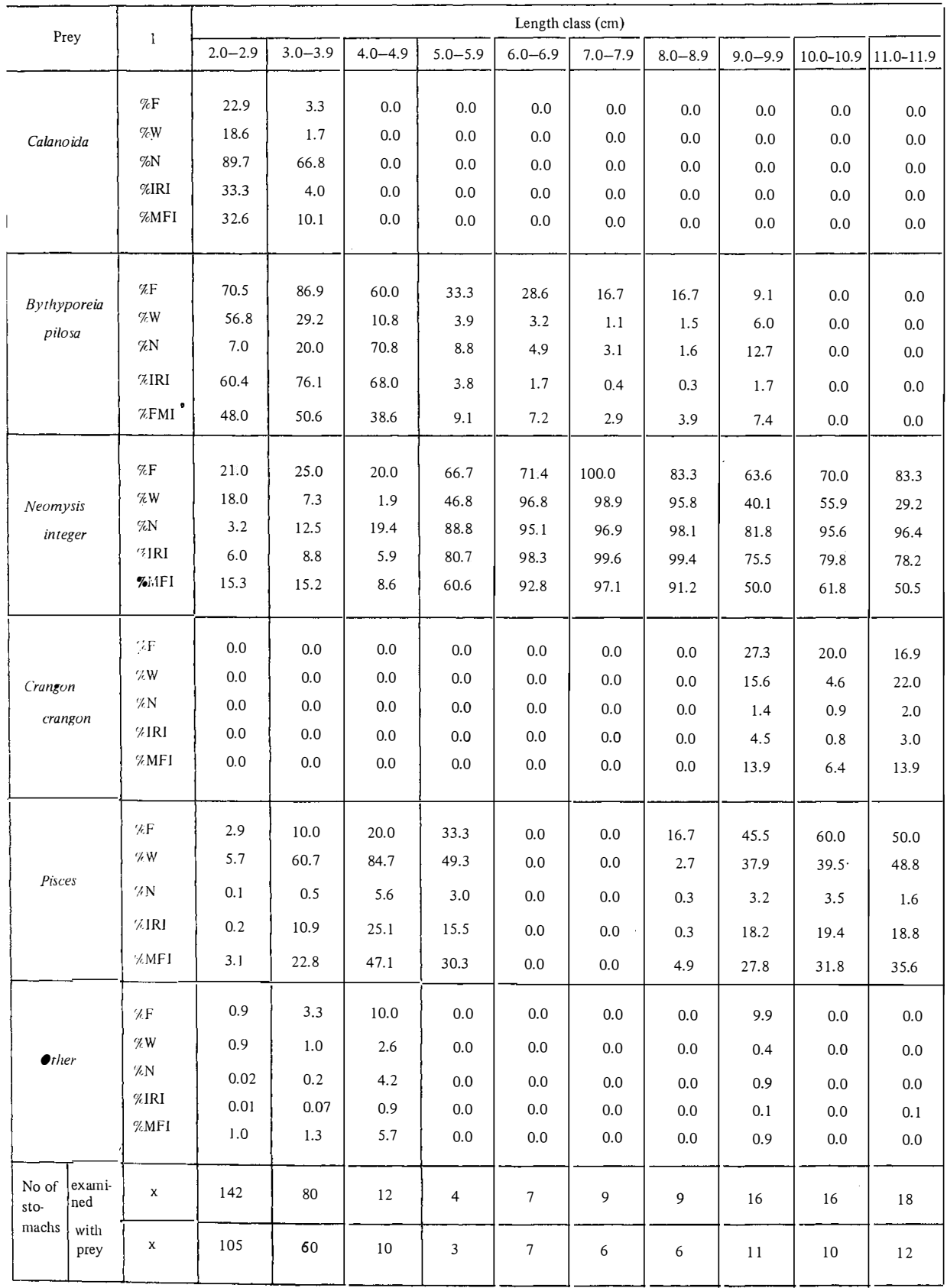




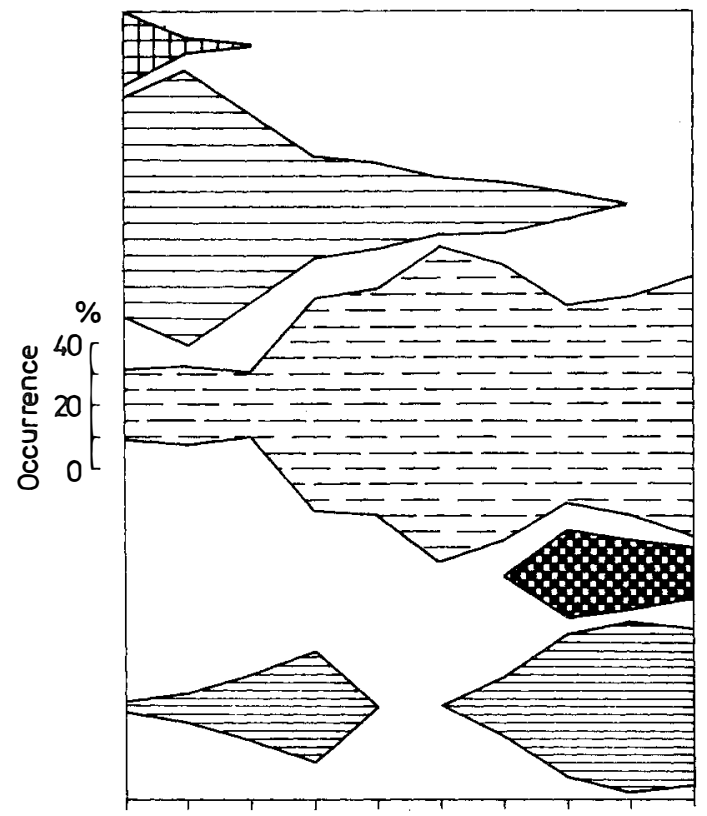

(a)

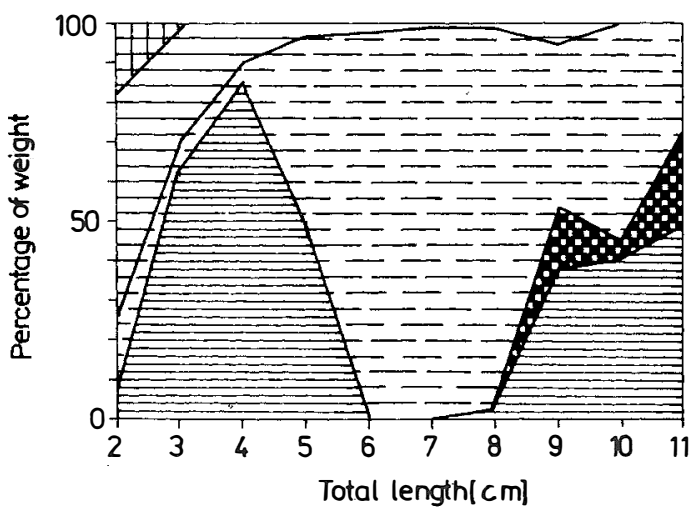

(b)
\# Calanoida
$\Theta$ Bathyporeia pilosa
E- Neomysis integer
Crangon crangon
帮 Pisces

Fig. 2. Psetta maxima. Prey composition by length classes. a: by frequency of occurrence (\%F); b: by percentage of weight (\%W), 
6. Other - Gammarus spp., Calliopius rathkei, Corophium volutator, Idotea spp. (not included in Fig. 2).

Planctonic calanoids were founa only in stomachs of the smallest fish, from length classes $2.0-2.9$ and $3.0-3.9 \mathrm{~cm}$ in length. Their importance in food were low, decreasing from 22.9 to $3.3 \%$ by frequency of occurrence and from $18.6^{\circ}$ to $1.7 \%$ by weight.

Nectobenthic species Bathyporeia pilosa played an important role in food of turbot $2.0-4.9 \mathrm{~cm}$ in length, representing $60.0-86.7 \%$ by frequency of occurrence and $10.8-56.8 \%$ by weight. In larger (and older fish) the importance of this prey itern fell down to $33.3-9.1 \%$ by frequency of occurrence and 1.1-6.0 by weight. In the food of fish larger than $10.0 \mathrm{~cm} \mathrm{~B}$. pilosa was not found. Percentage frequency of occurrence and percentage by weight of this species decreased gradually with increasing of fish length.

The next nectobenthic species, mysid Neomysis integer, gradually replaced B. pilosa in the food of turbot. It was found in stomach of fish from all length classes. $N$. integer played an important role as a prey item both by percentage occurrence and by weight. In fish smaller than $4.9 \mathrm{~cm}$ in length it formed only $20-25 \%$ by frequency of occurrence and $1.9-18.0 \%$ by weight but in larger fish $60-100 \%$ by frequency of occurrence and $29.9-98.9 \%$ by weight.

The brown shrimp, Crangon crangon, was for the first time found in the stomachs of turbot longer than $9.0 \mathrm{~cm}$. This species was the constant component of the food of large turbot, $9.0-11.9 \mathrm{~cm}$ in length (age group I), representing $16.7-27.3 \%$ by frequency of occurrence and $4.6-22.0 \%$ by weight.

Pisces were found in food of fish of nearly all length classes. The lack of this prey item in food of fish from length range $6.0-7.9 \mathrm{~cm}$ was caused rather by scarcity of data. Pisces occurred in the food of very early bottom-stages of turbot, just after metamorphose. The smallest turbot with "Pisces" prey item in stomach had $1.95 \mathrm{~cm}$ in length. In terms of weight Pisces formed the most important (49.3-84.7\%) part of the diet of turbot of length $3,0-5.9 \mathrm{~cm}$ (age group 0 ) with frequency of occurrence $10.0-33.3 \%$. In larger turbot, from length range $9.0-11.9 \mathrm{~cm}$, Pisces represented $37.9-48.8 \%$ of the total stomach contents by weight with frequency of occurrence $45.5-60.0 \%$.

The role of "Other prey" was negligible.

The differences between diet composition of 0 -and I-age group turbot were observed (Table 2., Fig. 3). In food of 0-age group turbot the major role in diet played small crustaceans, like Calanoida (5.6\% by weight and $13.5 \%$ by frequency of occurrence) and B. pilosa ( $30.4 \%$ by weight and $74.7 \%$ by frequency of occurence). $N$.-integer formed $12.6 \%$ of total stomach contents by weight and $23.0 \%$ by frequency of occurrence. Surprisingly high share of Pisces, $50.2 \%$ by weight, compared with only $6.7 \%$ by frequency of occurrence is likely to be overestimated. The value of $10-20 \%$ by weight could have been more proper rather in this respect to. $C$. crangon was totally lacking in the diet of smaller fish. In food of I-age group turbot the most important groups of prey both by weight $(47.1 \%)$, and by frequency of occurrence (76.8\%) was $N$. integer, Pisces (38.2\% by weight, and $34.6 \%$ by frequency of occurrence) and C. crangon (13.6\% and 13.5\% respectively). Calanoids were lacking in the diet of larger fish and importance of 
Table 2

Psetto maxima Comparison of prey composition between age group 0 and I.

Values used to calculate diet-overlap are underlined

\begin{tabular}{|c|c|c|c|c|c|c|c|c|c|c|}
\hline \multirow[b]{2}{*}{ Prey item } & \multicolumn{5}{|c|}{ age group $0 ; n=1.78$} & \multicolumn{5}{|c|}{ age group I; $n=52$} \\
\hline & $\% W$ & $\% \mathrm{~F}$ & $\% \mathbf{N}$ & \%IRI & $\%$ MFI & $\% \mathrm{~W}$ & $\% \mathrm{~F}$ & $\% \mathrm{~N}$ & \%IRI & $\%$ MFI \\
\hline Calanioids & 5.6 & 13.5 & 82.5 & 23.5 & 20.0 & -0.0 . & 0.0 & 0.0 & 0.0 & 0.0 \\
\hline B. pilose & 30.4 & 74.7 & 11.0 & 61.2 & 45.0 & $\overline{1.0}$ & 9.6 & 2.9 & 0.3 & 2.0 \\
\hline N. integer & 12.6 & 23.0 & 6.1 & 8.5 & 17.5 & $\overline{47.1}$ & 76.9 & 94.3 & 87.1 & 62.4 \\
\hline C. crangon & 0.0 & 0.0 & 0.0 & 0.0 & 0.0 & 13.6 & 13.5 & 1.0 & 1.6 & 9.8 \\
\hline Pisces & 50.2 & 6.7 & 0.3 & 6.7 & 16.2 & 38.2 & 34.6 & 1.7 & 11.1 & 25.4 \\
\hline Other & 1.2 & 2.2 & 0.1 & 0.01 & 1.2 & 0.06 & 1.9 & 0.1 & 0.002 & 0.2 \\
\hline
\end{tabular}

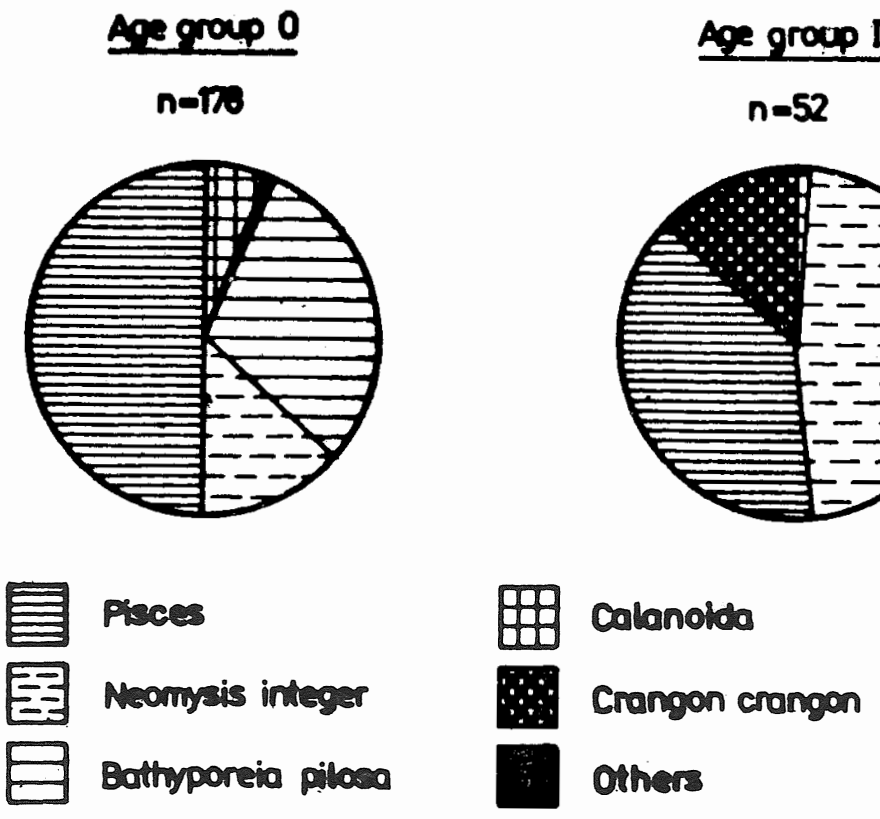

Fig. 3. Psetta maxima. Comparison of prey composition by percentage of weight of prey items in total stomach contents in age group 0 and $I$. 
Platichthys flesus. Prey composition by length classes. \%W: \% weight; $\% \mathrm{~F}: \%$ frequency of occurrence; $\% \mathrm{~N}: \%$ number; $\% \mathrm{IRI}, \% \mathrm{MFI}$ : percentage values of feeding indices of prey categories

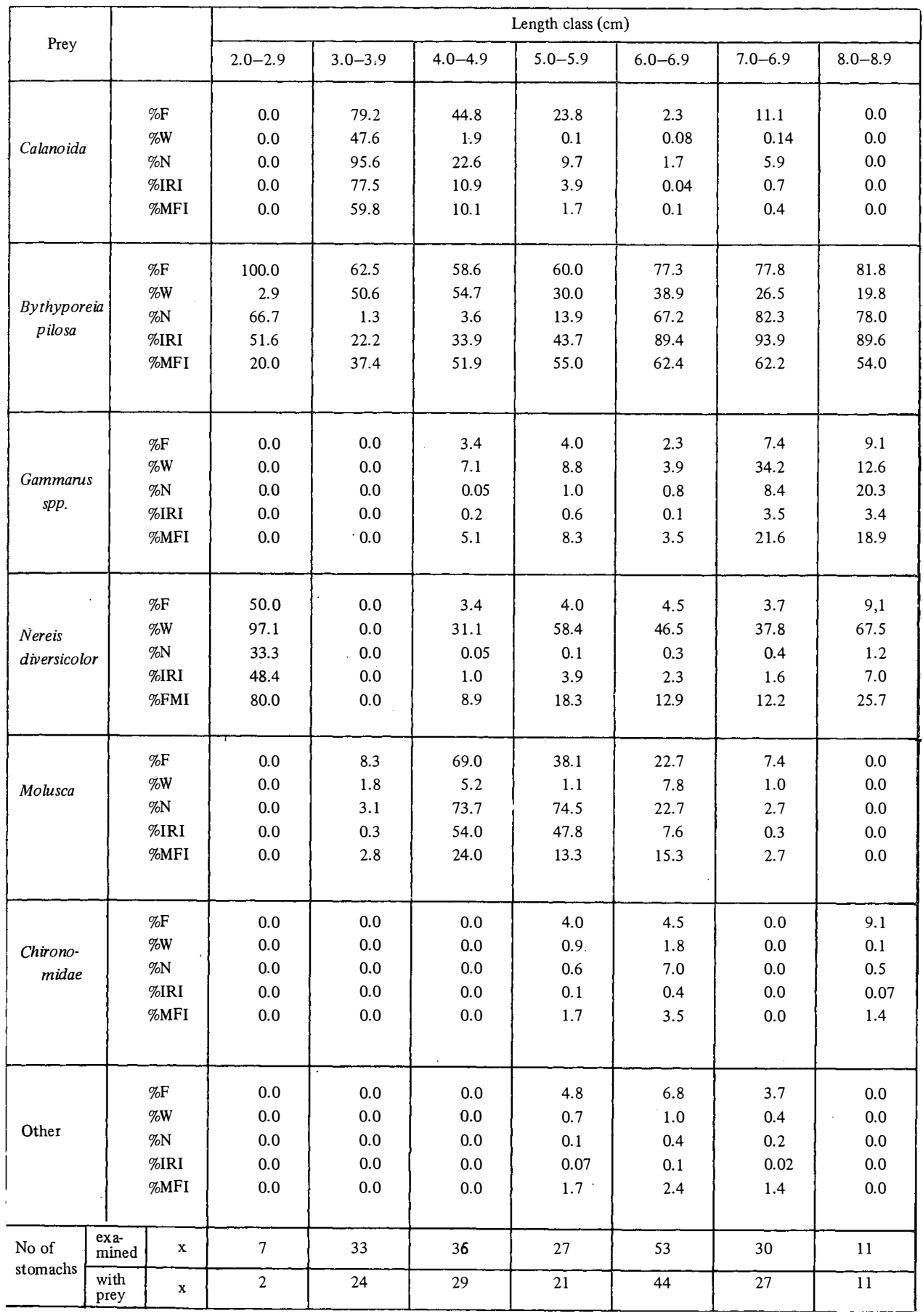


B. pilosa was minor ( $1 \%$ by weight and $9.6 \%$ by frequency of occurrence).

Owing to these differences diet-overlap between these two age groups (without taking Pisces into consideration) was low, not exceeding $14 \%$. With Pisces this value could have grown even to $52 \%$, but $25-30 \%$ is more likely.

Platichthys flesus. In the diet composition of the flounder seven components were found (Table 3., Fig. 4):

1. Calanoids - Centropages hematus, Temora longicornis, Pseudocalanus elongatus, Acartia spp., Eurytemora spp.,

2. Amphipod - Bathyporeia pilosa.

3. Gammarids - Gammarus oceanicus, G. zaddachi

4. Polychaete - Nereis diversicolor.

5. Molluscs - Cardium edule, Macoma baltica, Mytilus edulis, Hydrobia ulvae.

6. Chironomids larvae.

7. Other - Neomysis spp., Calliopius rathkei, Corophium volutator, Asellus aquaticus, Idotea granulosa (not included in Fig. 4).

Planctonic calanoids were found in nearly all length classes but the smallest, 2.0-2.9 and the largest, $8.0-8.9 \mathrm{~cm}$ in length. The lack of calanoids in the diet of the smallest fish was caused most likely by the very small size of this sample (only 2 fish with prey in stomach); as in the next length class, 3.0-3.9 calanoids share was $47.6 \%$ by weight and 79.2 by frequency of occurrence. In next length classes a drastic drop in the importance of calanoids in food composition were observed.

Bathyporeia pilosa found in food of fish from all length classes was an important prey item of juvenile flounder. In smaller fish it formed more than $50 \%$ of the total stomach contents be weight and by frequency of occurrence. It decreased gradually with increasing length of flounder but in the largest fish still formed nearly $20 \%$ by weight and $82 \%$ by frequency of occurrence.

B. pilosa was followed by gammarids species, Gammarus spp., which occurred of fish from length range $4.0-8.9 \mathrm{~cm}$ and formed $3.9-34.2 \%$ of the stomach contents by weight and $2.3-9.1 \%$ by frequency of occurrence.

The polychaete, Nereis diversicolor, represented $31.1-67.5 \%$ of the total stomach contents by weight but only $3.4-9.1 \%$ by frequency of occurrence, in the diet of fish longer than $4.0 \mathrm{~cm}$. In the smallest fish the weight share of this prey item was extremely high due to the scarcity of data. Though according to weight method $N$. diversicolor was the most important as a food item in flounder the comparison of values of $\%$ IRI and \%MFI for $B$. pilosa and $N$. diversicolor revealed greater importance of the former.

The tiny bottom-stages of Mollusce occurred in the food of fish from length range $3.0-7.9 \mathrm{~cm}$, and especially frequently in two length classes, $4.0-4.9$ and $5.0-5.9 \mathrm{~cm}$, with frequency $69 \%$ and $38 \%$ respectively, but played insignificant role according to weight method.

The role of Chironomidae and "Other prey" in food of flounder were negligible. 

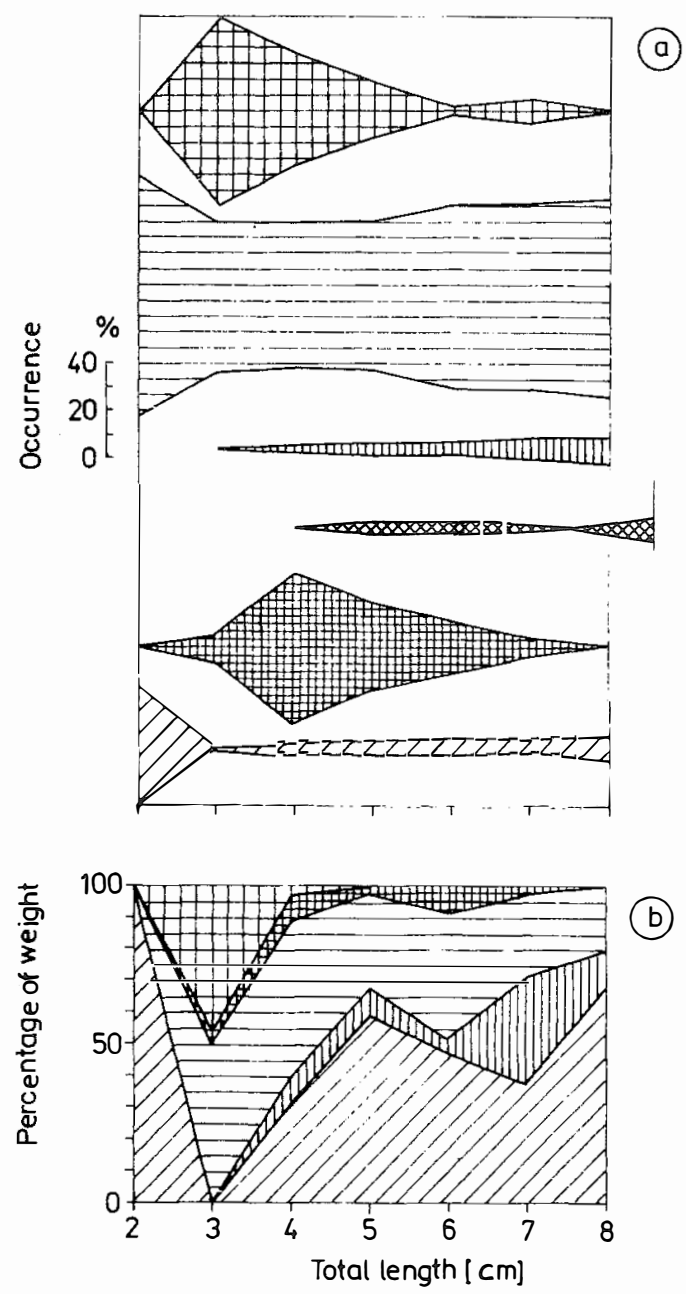

(b)

Calanoida
Bathyporeia pilosa
Gammarus spp.
Chironomidae
Nereis diversicolor
Mollusca

Fig. 4. Platichthys flesus. Prey composition by length classes. a: by frequency of occurrence (\%F); b: by percentage of weight $(\% \mathrm{~W})$. 
The main bulk of food of flounder in both age groups was formed by crustaceans (Tab. 4 Fig. 5). During the growth of fish smaller forms like Calanoida were soon replaced

Platichthys flesus. Comparison of prey composition between age group 0 and $\mathbb{I}$.

Values used to calculate diet-overlap are underlined

\begin{tabular}{|c|c|c|c|c|c|c|c|c|c|c|}
\hline \multirow{2}{*}{ Prey item } & \multicolumn{5}{|c|}{ Age group $0 ; n=55$} & \multicolumn{3}{|c|}{ Age group I; } & \multicolumn{2}{|c|}{$\mathrm{n}=103$} \\
\hline & $\% \mathrm{~W}$ & $\% F$ & $\% \mathbb{N}$ & $\% \mathbb{R} \mathbb{I}$ & $\% \mathbb{I M F I}$ & $\% \mathrm{~W}$ & $\% F$ & $\% \mathbb{N}$ & $\% \mathbb{I R I}$ & $\% \mathrm{MFI}$ \\
\hline Caisnoida & 9.8 & 58.2 & 69.1 & 51.8 & 30.1 & 0.04 & 8.7 & 5.4 & 0.6 & 0.7 \\
\hline B. pilose & 43.7 & 81.8 & 2.2 & 40.0 & 44.6 & 28.4 & 76.7 & 51.5 & 84.2 & 58.1 \\
\hline Gammarus spp. & 4.4 & 1.8 & 0.02 & 0.09 & 2.4 & $\overline{17.1}$ & 4.8 & 4.4 & 1.4 & 12.2 \\
\hline N. diversicolor & $\overline{38.5}$ & 3.6 & 0.04 & 1.6 & 9.6 & 50.8 & 4.8 & 0.3 & 3.4 & 14.9 \\
\hline Mollusca & 3.6 & 40.0 & 28.7 & 14.6 & 13.3 & 2.6 & 19.4 & 35.6 & 10.2 & 10.8 \\
\hline Chironomidae & 0.0 & 0.0 & 0.0 & 0.0 & 0.0 & $\overline{0.6}$ & 3.9 & 2.5 & 0.2 & 1.9 \\
\hline Other & 0.0 & 0.0 & 0.0 & 0.0 & 0.0 & 0.5 & 4.8 & 0.2 & 0.04 & 1.5 \\
\hline
\end{tabular}
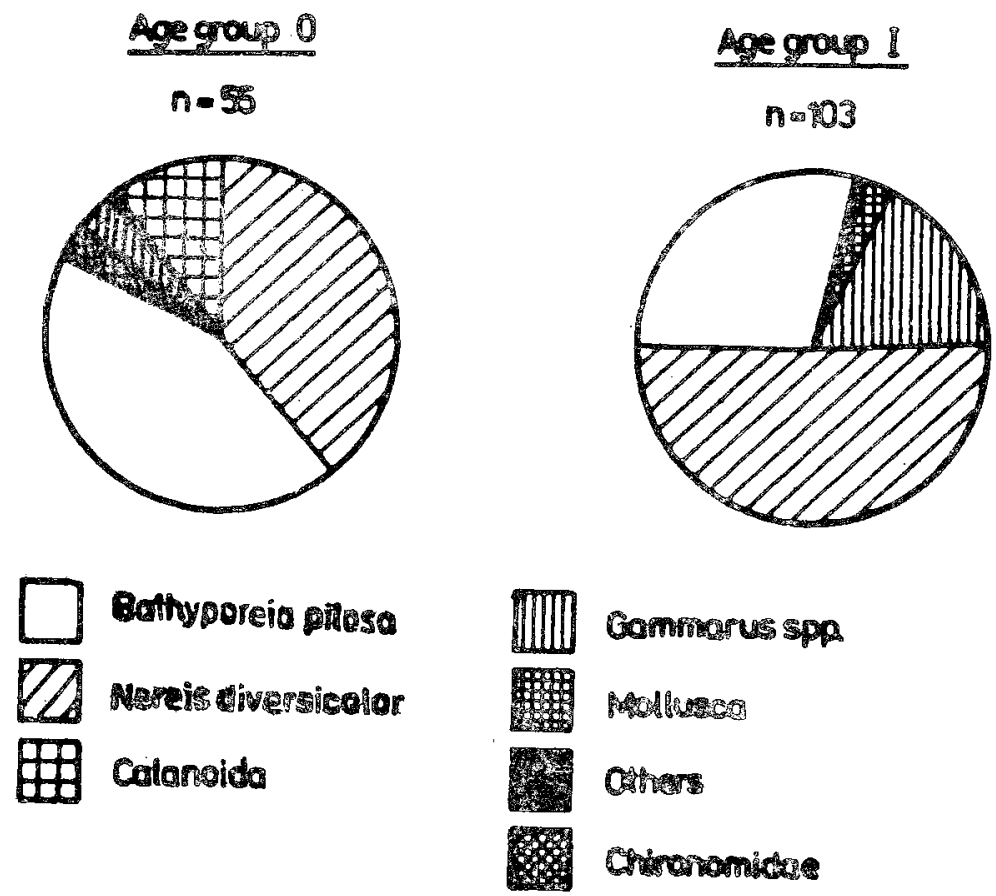

Comporuspa

74.

Q

monomidtes

Fig. 5. Platichthys flesus. Comparison of prey composition by percentage of weight of prey items in total stomach contents in age group 0 and I. 
Comparison of prey composition of turbot, Psetta maxima, and flounder, Platichthys flesus, by percentage of weight (\%W) of prey items in total stomach contents (all data). Values used to calculate diet-overlap between these two species are underlined

\begin{tabular}{|l|c|c|}
\hline \multicolumn{1}{|c|}{ Prey item } & Psetta maxima & Platichthys flesus \\
\hline Calanoida & 0.7 & $\underline{0.6}$ \\
B. pilosa & $\frac{4.8}{0.0}$ & 29.2 \\
Gammarus spp. & $\frac{0.7}{42.7}$ & 16.4 \\
N. integer & $\underline{0.0}$ & $\frac{0.0}{50.2}$ \\
N. diversicolor & $\underline{0.0}$ & 2.6 \\
Mollusca & $\underline{0.0}$ & 0.6 \\
Chironomidae & 11.8 & $\underline{0.0}$ \\
C. crangon & 39.7 & $\underline{0.0}$ \\
Pisces & $\underline{0.2}$ & 0.5 \\
Other & $\underline{2}$ & \\
\hline
\end{tabular}

by $B$. pilosa, and this gradually by Gammarus spp. The main food item by weight method in both age groups was $N$. diversicolor, but its share in food composition due to hight weight standards is overestimated.

Similar prey composition of stomach contents of flounder from age group 0 and I resulted in high diet-overlap, $73.9 \%$ by percentage of weight. Smaller share, of rather overestimated $N$. diversicolor, in food of 0-group flounder could have given a diet-overlap not exceeding $50 \%$.

Diet - overlap between juvenile turbot and flounder.

Differences in prey composition resulted in moderate diet-overlap between fish from age group 0 , and practically no overlap between age groups $\mathbb{I}$, as in all data for both age groups taken together. The only food shared in bigger amount was $B$. pilosa. Diet-overlap between 0-group fish (with only two food items shared, Calanoida and B. pilosa) attained as much as $36 \%$ (in $\%$ W, Table 2 and 4 ). Between fish from age groups I diet-overlap attained only $1 \%$ (Table 2 and 4), and in both age groups (all data) $5.6 \%$.

\section{DISCUSSION}

Juvenile flatfish abundance and distribution is connected with water depth, avoiding larger predators, obtaining suitable food and cover (Riley et al, 1981). Shallow, inshore nursery ground at Swiętouść, Pomeranian Bay, utilized by juvenile turbot and flounder meets all these requirements. Most of the sampled area formed sandy bars, not exceeding $1 \mathrm{~m}$ at depth, usually much shallower, parallel to the shoreline, covered with the so 
called" moving sands", with big stones scattered sparsely. In some places narrow strips of gravel bordered on the very shore (Szlakowski, 1985). Mulicki (1959) stated the Pomeranian Bay is a feeding ground for young flatfish.

The food composition of juvenile flatfish preying in this habitat reflected to some extent abundance and distribution of prey organisms. The "moving sands" habitat is inhabited mostly by crustaceans, like Bythyporeia pilosa, Neomysis integer, Crangon crangon and polychaete Nereis diversicolor (Żmudzinski, 1982), which also formed the main bulk of food, both of turbot and flounder. The prey organisms which formed the prey item "Other" and were found in the food of flatfish in very few quantities, like Gammarus spp., Calliopius rathkei, Corophium volutator, small isopods and molluscs abide at big stones (personal observation).

De Groot (1971) in detailed studies on the feeding of flatfish showed that turbot belong to the predatory flatfish, fish-feeders, and flounder to the benthophagic group of flatfish, crustaceans feeders, but also feeding on molluscs and polychaetes. According to Hertling (1928) turbot lived mainly on fish, the large ones especially on Ammodytes, the smaller on Gobius, also on crustanceans, such as mysids and Crangon. Müller (1968) found that juvenile turbot, $1.9-7.0 \mathrm{~cm}$ in length (caught in the Baltic near the island of Bornholm, during its first summer) fed mainly on fish (Ammodytes tobianus, Pomatoschistus spp.) and amphipods (Gammanus zaddachi, G. locusta, C. volutator). Mysids (mainly N. integer) and isopods (Eurydice pulchra, Idotea viridis) were secondary food animals. Malacostraca formod $90 \%$, and Pisces $10 \%$ of food contents by number method. According to Müller, the presence of crustaceans and fish, but the lack of polychaetes and oligochaetes, in the food of 0-group turbot indicate predatory way of life from the very begining. De Groot (1971) stated the juvenile turbot from North Sea, up to $10 \mathrm{~cm}$ in lenght, fed primarily on polychaetes and molluscs; and that fish from length range 11-20 cm fed on crustaceans, mostly Crangon. Turbot over $20 \mathrm{~cm}$ in length was rish-feeder. Similarly, Braber and De Groot (1973) recorded mysids and young brown shrimp, C. crangon' as a food of juvenile turbot from the coastal waters of Netherlands. Older juveniles fed on adult shrimp. Fish as food for the first time were found in turbot with length $11 \mathrm{~cm}$. Turbot from length range $11-30 \mathrm{~cm}$ relied mainly on fish, whereas from length range $31-65 \mathrm{~cm}$ were exclusively fish-feeders. The first fish species found was the goby, Gobius spp., then Osmems eperlanus, Ammodytes, pleuronectids and gadoids. The fish mainly preyed on was sandeel, Ammodytes tobians, and as turbot grew larger, gadoids. Jones (1973) found many components in the food of juvenile turbot from coastal waters of Wales: Amphipoda, Cumacea, Isopoda, Mysidacea, Crangon, Brachyura, Mollusca, Polychaeta, Pisces and dipteran larvae. Mysids and polychaetes were the most important.food items both by percentage occurrence and by weight, while amphipods and isopods taken frequently were of minor importance by weight. Pisces were taken only by larger $(10-15 \mathrm{~cm})$ turbot, at the start of the second year of life.

From the above review, two differences in feeding of juvenile turbot from the Baltic and North Sea result. Firstly, the lack of benthic organisms, like polychaetes and molluscs in the diet of Baltic turbot, and their presence in the food of North Sea turbot Secondly, 
the presence of fish in the diet of very young bottom-stages of Baltic turbot, and their lack in the diet of North Sea turbot, up to $10 \mathrm{~cm}$ in length. As polychaetes and molluscs occurred in the food of juvenile flounder dwelling together with turbot, their lack in the diet of Baltic turbot (that is were available in the environment but were nor eaten) was most likely connected with some food selectively, abundance of prey fitting more properly to turbot's feeding habits (in wide meaning, ad described by De Groot, 1971), and practically no competition with other fish species.

Data presented in this paper revealed that turbot from early bottom-stages is a predatory fish, feeding actively on moving prey. Also distinct shifts in prey preference as a function of fish size were observed. As fish grew larger small food items, like Calanoida and $B$. pilosa were neglected in favour of $N$. integer, C. crangon and Pisces; which yielded far more energy per individual item. Polychaetes and molluscs were totaly lacking, in the diet of juvenile turbot. Such size-dependent predation may minimize diet-overlap between small and larger fish.

Extensive studies on feeding of flounder revealed that food composition of this species vary much, and depend on size/age of fish, season of the year, locality, abundance, availability and behaviour of the prey (Hertling, 1928; Mulicki, 1947; Bokova, 1954; Zeltenkova, 1954; Moore and Moore, 1976; Szypuła and Załachowski, 1978). But in spite of differences certain features of feeding of juvenile flounder are common. Small crustanceans, Calanoida, Cyclopoida, Harpacticoida, Cladocera and Ostracoda are the principal food of the youngest bottom-stages of 0 -group flounder, up to $3.0 \mathrm{~cm}$ in length (Blegvad, 1932; Mulicki, 1947; Szypuła and Załachowski, 1978). Larger flounder feed on amphipods (mostly Bathyporeia spp. and Gammarus spp.), isopods and mysids (mostly $N$. integer). Polychaete, $N$. diversicolor is often an important food item too. Such food items as Mollusca, Pisces and Chironomidae generally play rather minor role in the food of juvenile flounder (Blegvad, 1932): But adult flounder predominantly consume molluscs, in addition crustaceans, few worms and very few fish (Hertling, 1928; Mulicki, 1947; Żeltenkova, 1954). Szlalkowski (own data) found that juvenile flounder, length range $6.0-9.0 \mathrm{~cm}$, caught at Kołobrzeg in July 1980, fed heavily on gobiids, Pomatoschistus spp. According to Heesle (1930) chironomids played important role in the food of 0 and I-group flounder. Similarly, Szypuła and Załachowski (1978) found that chironomids formed $40.6 \%$ of food contents by weight of juvenile flounder caught in channel connecting lake Jamno with Baltic Sea.

So, food composition (and its changes during the growth of fish) of juvenile flounder at Świętouść, reflected feeding ecology and feeding possibilites of this fish at this ground. Calanoida, forming the basic food of the smallest flounder, were replaced by amphipods, B. pilosa and Gammarus spp., and polychaete, N. diversicolor, as fish grew in size. Mollusca, Chironomidae and the "Other food" item played minor role in food of juvenile flounder.

As regards $N$. integer, heavily preyed on by turbot (this paper), only one specimen was found in the food of flounder, so it was put into the prey item "Other". This stay in contrast with findings of other authors (Bokova, 1954; Moore and Moore, 1976; Szypula 
and Zalachowski, 1978), who reported $N$. integer as an important food item. Thus, as this species was not practically eaten at Swiętouść, other organisms, amphipods in this respect, were preyed more heavily instead.

In both species examined changes in food composition during the growth in lenght were observed. Smaller food items were neglacted in favour of larger prey. Few, 6-7, prey items were ingested, but only 2-3 formed the main bulk of food in both species. Owing to differences in feeding ecology the prey composition of juvenile turbot and flounder were diverse; and thus diet-overlap, especially in larger, I-group, juveniles, was minimized. Dier-overlap between O-group fish, for two prey items, Calanoida and B. pilosa, shared, attained $36 \%$.

The food competition could have been significant between the smallest fish, which fed mostly on Calanoida, and $R$. pilosa, but the very young bottom-stages of turbot fed on Pisces 100 , and flounder on $N_{0}$ diversicolor respectively. Besides, newly-metamorphosed turbot, $2.0-2.9 \mathrm{~cm}$ in lenght, feeding on calanoids and $B$. pilosa, appeared at Swiętousć in the mid of July (Szlakowski, 1985), while flounder even to one month earlier (au thors observations). During the period studied differences in abundance of the smallest fish from both species occurred. Flounder was presented by larger fish, very few from length class $2.0-2.9 . \mathrm{cm}$.

\section{REFERENCES}

Rlegvad Hog.1932: On the flounder (Pleuronetes flesus) and the Danish Flounder Fishery in the Baltic. Rapp. P.-v. Reun. Cons int. Explor. Mer 78: 1-28.

Bolsova E.N., 1954: Pitanije molodi promyslowych ryb Baltijskogo Moria. Trudy VNIRO 26: 163-187. (in Russian).

Braber L., S.J. De. Groot, 1973: The food of five flatrish species (Pleuronectiformes) in the southern North Sea. Neth. J. Sea Res 6: 163-172.

Czislenlso L.L., 1968: Nomogramy dla opredelenia vess vodnych organizmov po razmeram i formie tela. Itd. "Naukg", Leningrad. (in Russian).

Groot.S.J.De., 1971: On the interrelationships between morphology of the alimentary tract, food and feeding behaviour in flatfishes (Pisces: Pleuronectiformes). Neth. J. Sea Res 5: 121-196.

Herting Ho, 1928: Untersuchungen ü ber die Ernährung von Meeresfischen. I. Quantitative Nahrungsuntersuchungen an Pleuroinectiden und einiger anderen Fische der Ostsee. Ber. Di. W1ss. Romm. Meeresforch. N.F. 4(2): 1-124.

Hessle Chr., 1930: The young bottomstages of the flounder (Plewronectes fle northern part of Gothnd. Svenska Hydrogr.-Biol. Kommis. Skrifter Ny Serio: Biologi Band 1. NI 4.

Jones A, 197.3: The ecology of young turbot, Scophthalmus maximus (L.), at Borth, Cardiganshire, Wales. J. Fish Biol S: 367-383.

KCostrzewsisa I.o, 1985: Biologia naryblsu i mlodzieży stomi, Platichthys flesus (Linne, 1758) z Zatoki Pomorskiej i z Zatoki Gdańskiej. Praca magisterska, maszynopis. Zaklad Biologii Ryb Akademii Rolniczej w Szczecinie. [The biology of juvenile and young flounder, platichthys fless (Linne, 1758), from Pomeranian Bay and Gdanisk Bay. M. Sc. Thesis, Department of Fish Biology, Academy of Agriculture, Szczecin].

Moore J.W., I.A. Moore, 1976: The basis for food selection in flounders, Platichthys flesus (L.), in the Serezo Estuary. Io Eish BiOL 2: 139-156. 
Mulicki Z., 1947: Odżywianie się storni (Pleuronectes flesus L.) w Zatoce Gdańskiej. [The food and feeding habit of the flounder (Pleuronectes flesus L.) in the Gulf of Gdańsk]. Arch. Hydrobiol. i Ryb. 13: 221-259. (in Polish with English summary).

Mulicki Z., 1959: The status of the south Baltic flatfish stock. Rapp. P.-v. Reun. Cons. int. Explor. Mer 147: 39-47.

Muller A., 1968: Die Nahrung junger Plattfische in Nord-und Ostsee. Kieler Meeresforsch. 24: $124-143$.

Pinkas L., M.S. Oliphant, I.L.K. Iverson, 1971: Food habits of albacore, bluefin tuna and bonito in California Waters. Fish. Bull. Calif. 152: 1-105.

Rilley J.D., D.J. Symonds, L. Woolner, 1981: On the factors influencing the distribution of 0-group demersal fish in coastal waters. Rapp. P.-v. Reun. Cons. perm. int. Explor. Mer 178: 223-228.

Shorygin $A_{0} A_{0}, 1952$ : Pitanije i piscevyje vzaimootnosenija ryb Kaspijskogo Moria. Izd. "Piszczepromizdat", Moskva (in Russian).

Szlakowski J., 1985: Badania nad biologią skarpia, Psetta maxima (L.), z Zatoki Pomorskiej. Praca magisterska, Zakład Biologicznych Zasobów Morza Akademii Rolniczej w Szczecinie. [Studies on the biology of turbot, Psetta maxima (L.), from Pomeranian Bay. M. Sc. Thesis, Department of Biological Resources of the Sea, Academy of Agriculture, Szczecin].

Szypuła J., W. Załachowski, 1978: Badania nad biologią storni bałtyckiej w przybrzeżnej strefie rejonu Kołobrzesko-Darłowskiego. [Studies on .biology of juvenile Baltic flounder in the inshore zone off the Kołobrzeg-Darłowo region]. Zesz. nauk AR Szczecin. Ser. Ryb. morskie 70: 27-40. (in Polish with English summary).

Zander C.D., 1982: Feeding ecology of littoral gobiid and blennioid fish of the Banyuls area (Mediterranean Sea). I. Main food and trophic dimension of niche and ecotope. Vie Milieu 32:1-10.

Zeltenkova M.V., 1954: Recnaja kambala (Pleuronectes flesus trachurus vuncker) kak osnovoj potrebitel molluskov Baltijskogo Moria. Trudy VNIRO 26: 137-162. (in Russian).

Zmudziński L., 1982: Zoobentos litoralu Bałtyku. W: Ż́mudziński L., Ostrowski J., Zoobentos Bałtyku lat sześćdziesiątych. [Baltic Sea littoral zoobenthos. In: Żmudziński L., Ostrowski J., Baltic Sea zoobenthos of the sixties]. WSP Słupsk 82:5-38 (in Polish with English summary).

Iwona Kostrzewska-Szlakowska, Jacek Szlakowski

\section{LETNI POKARM NARYBKU SKARPIA, PSETTA MAXIMA (L.) I STORNI, PLATICHTHYS FLESUS (L.), Z REJONU ŚWIETOUŚCIA, ZATOKA POMORSKA}

\section{STRESZCZENIE}

Zbadano zawartošć 313 żołądków narybku skarpia, Psetta maxima (Lo), i 197 przewodów pokarmowych stomi, Pletichthys flesus (L.), występujących razem, licznie, na płytkowodnym, przybrzeżnym żerowisku narybkowym w rejonie Świętouścia, Zatoka Pomorska (Rys. 1).

W pokarmie skarpia wyodrębniono szesć składników: planktonowe Calanoida, Bathyporeia pilos, Neomysis integer, Crangon crangon, Pisces i inne. Wraz ze wzrostem narybku zmieniało się znaczenie poszczególnych składników w jego pokarmie (Rys. 2 i 3, Tabela 1 i 2). Calanoide występowały tyllıo w pokarmie najmniejszego narybku, do $2.9 \mathrm{~cm}$ długości. Znaczenie B. pilosa; początkowo najważniøjszego składnika pokarmu, w miare wzrostu naryblku sukcesywnie spadało, a podstawą pokarmu stały się N. integer i Pisces Pisces występowały już w pokarmie najmniejszego skarpia, zaraz po jego przejściu do dennego trybu życia. C. crangon, duży i ruchliwy skorupiak, pojawił się dopierow pokarmie większego narybku, powyżej $9.0 \mathrm{~cm}$ długości.

W pokarmie storni wyodrębniono siedem składnilków: Calanoida, B. pillosa, Gammarus spp., Nereis diversicolor, Mollusca, Chironomidae i inne (Rys. 4 i 5, Tabela 3 i 4). Calanoida były obecne $w$ 
pokarmie ryb należących do prawie wszystkich klas długości, ale większe znaczenie odgrywały tylko w pokarnie ryb małych, do $3,9 \mathrm{~cm}$ długości. Pokarmem o największym znaczeniu była $B$. pilosa (według częstości występowania i indeksów pokarmowych IRI i MFI), wyprzedzając $N$. diversicolor, której udział w pokarmie, oparty na zrekonstruowanych masach standardowych, i przy małej częstości występowania, wydaje się zawyżony (podobnie jak udział Pisces w pokarmie narybku skarpia z grupy wieku 0). Spośród pozostałych składników pokarmu największe znaczenie miały Gammarus spp.

Wśród narybku skarpia i storni z grupy wieku o zbieżność pokarmowa dla wspólnych składników pokarmu, Calanoida i B. pilosa, wyniosła $36 \%$. Dzięki różnicom w składzie pokarmu wśród ryb z grupy wieku I, zbieżność pokarmowa nie przekroczyła $1 \%$, a dla całego badanego materiału $6 \%$ (Tabela 5).

Author's address:

Received: 1990.01 .08

Mgr Jacek Szlakowski,

mgr Iwona Kostrzewska-Szlakowska

Instytut Oceanografii Rybackiej

i Ochrony Morza

ul. Kazimierza Królewicza 4

71-550 Szczecin

Polska (Poland) 